\title{
EKSTRAK DAUN ASAM JAWA (Tamarindus Indica L.) SEBAGAI ANTIDIABETES
}

\author{
Tamarind (Tamarindus indica L.) Leaves Extracts as Antidiabetic
}

\author{
* Olfiana T. Lahamado, Sri M. Sabang, dan Kasmudin Mustapa
}

Pendidikan Kimia/FKIP - Universitas Tadulako, Palu - Indonesia 94118

Recieved 01 December 2016, Revised 02 January 2017, Accepted 02 February 2017

\begin{abstract}
One of the plant that is widely used as a medicinal plant is the leaves of tamarind (Tamarindus indica L). This study aims to determine the effectiveness of anti-diabetic of tamarind (Tamarindus indica L.) extract in lowering blood glucose levels in mice animals test. The experiment was performed using tamarind leaves extracted through infusion method. The animals test were 15 male mice induced by ethylene diamine tetra acetate (EDTA). Mice were divided randomly into 5 groups with different treatments. Treatments I, II and III were given tamarind leaves extracts for each with a concentration of $10 \%, 20 \%$ and $40 \%$. Treatment IV was given glibenclamide suspense as a positive control ( + ), and the treatment $V$ was given $\mathrm{Na}-\mathrm{CMC} 1 \%$ as a negative control (-). Based on the analysis of variance statistical calculations tamarind leaves extracts can lower blood glucose levels on mice test. Furthermore, the significant difference was tested to check the concentration effect. The results on animals test with a significant level of $5 \%$ showed that the tamarind leaves extract of $40 \%$ or Treatment III affected on decreasing blood sugar levels on mice.
\end{abstract}

Keywords: Ptamarind leaves, diabetes mellitus, antidiabetic, mice.

\section{Pendahuluan}

Diabetes melitus merupakan kumpulan gejala yang timbul pada seseorang akibat kadar gula darah yang tinggi (Waspadji, 2007). Diabetes mellitus merupakan penyakit gangguan metabolisme, di mana kadar glukosa darah di atas normal dan merupakan salah satu masalah dalam kesehatan masyarakat. Penderita penyakit ini dari tahun ke tahun cenderung meningkat (Sutjiatmo, dkk., 2011) Diabetes melitus adalah suatu sindrom yang ditandai hiperglikemia kronis lama kelamaan akan menyebabkan komplikasi yaitu mikroangiopati yang menyebabkan komplikasi pada mata (retinopati), ginjal (nefropati), saraf (neuropati), dan makroangiopati yaitu terjadinya aterosklerosis yang mengakibatkan penyakit jantung koroner dan struk.

Diabetes mellitus seringkali menimbulkan komplikasi pada berbagai organ tubuh jika tidak ditangani dengan tepat. Hal ini berkaitan dengan kadar gula darah yang tinggi dalam

*Correspondence:

Olfiana T. Lahamado

Program Studi Pendidikan Kimia, Fakultas Keguruan dan Ilmu Pendidikan, Universitas Tadulako

email: olfianatahsir@gmail.com

Published by Universitas Tadulako 2017 jangka waktu lama, sehingga berakibat rusaknya pembuluh darah, saraf, dan struktur internal lainnya (Kendran, dkk., 2010).

Penyakit kronis ini disebabkan oleh dua hal yaitu, ketidakmampuan tubuh dalam memproduksi insulin Diabetes tipe 1 dan insulin yang dihasilkan oleh tubuh tidak dapat bekerja dengan baik Diabetes tipe 2 (Dyahnugrah \& Widjanarko, 2015). Penyakit ini juga ditandai dengan gangguan metabolisme karbohidrat, lemak, dan protein yang dicirikan oleh kadar gula dalam darah (hiperglikemia) dan dalam urin (glukosuria) yang tinggi (Zubaidah, 2011).

Berdasarkan hasil survey yang dilakukan oleh organisasi kesehatan dunia/WHO, Indonesia merupakan negara keempat terbesar untuk prevalensi diabetes melitus setelah India, Cina, dan Amerika Serikat (Sukandar, dkk., 2012). Prevalensi tertinggi terdapat DI Yogyakarta (2,6\%), DKI Jakarta $(2,5 \%)$, Sulawesi Utara (2,4\%), dan Kalimantan Timur $(2,3 \%)$. Prevalensi diabetes mellitus yang terdiagnosis atau gejala tertinggi, terdapat di Sulawesi Tengah (3,7\%), Sulawesi Utara $(3,6 \%)$, Sulawesi Selatan $(3,4 \%)$, dan Nusa Tenggara Timur (3,3\%) (Trihono, 2013). 
Pengobatan diabetes mellitus yang digunakan dalam dunia kedokteran adalah dengan injeksi insulin dan obat hipoglikemik oral $(\mathrm{OHO})$ sintetik. Obat hipoglikemik oral tersebut disintesis dari golongan sulfonilurea, biguanid, tiazolidindion, dan meglitinida. Glibenklamid adalah salah satu yang merupakan obat antidiabetika golongan sulfonilurea yang sukar larut dalam air dan larut dalam alkohol. Setelah pemberian oral, glibenklamid dapat diabsorbsi dengan cepat dan baik. Glibenklamid diberikan dalam dosis tunggal, dosis sehari 5 $20 \mathrm{mg}$. Bila pemberian dihentikan, obat akan bersih dari serum setelah 36 jam. Glibenklamid menurunkan kadar glukosa darah pada diabetes mellitus tipe 2 dan tidak pada diabetes mellitus tipe 1. Mekanisme kerjanya menstimulasi sekresi insulin, meskipun secara kualitatif golongan sulfonilurea mempunyai efek farmakologi yang sama tetapi secara kuantitatif ada bedanya (Baroroh, 2011).

Penggunaan obat-obat sintesis relatif mengeluarkan biaya yang cukup mahal dan menghasilkan efek samping. Oleh karena itu, maka diperlukan obat alternatif dari berbagai jenis tumbuhan untuk mengobati penyakit dengan efek samping yang sangat kecil. Obat tradisional yang mengandung metabolit sekunder dapat digunakan sebagai alternatif untuk pengembangan obat karena lebih mudah diterima oleh tubuh dibandingkan obat sintetik (Galih \& Esyanti, 2014).

Lebih dari 70 persen tanaman obat yang ada di Asia tumbuh di Indonesia, tetapi masih belum banyak dimanfaatkan secara maksimal. Oleh karena itu, perlu upaya sungguh-sungguh dalam melibatkan berbagai pihak untuk mengangkat citra tanamana obat Indonesia yang telah lama dikenal agar bisa disejajarkan dengan obat modern, dan dapat memberi nilai ekonomis dan nilai sosial bagi masyarakat Indonesia (Inawati, dkk., 2006). Pengobatan tradisional sebagian besar menggunakan ramuan yang berasal dari tumbuh-tumbuhan baik berupa akar, batang, biji, bunga, daun, ataupun kulit kayu. Bagian-bagian dari tumbuhan tersebut mengandung senyawa metabolit sekunder yang terdiri dari empat golongan utama, yaitu steroid, flavonoid, alkaloid, dan terpenoid. Senyawa metabolit sekunder tersebut memiliki aktivitas biologis.

Penggunaan tanaman obat telah banyak digunakan untuk penanganan berbagai macam penyakit diabetes mellitus. Penggunaan tersebut dimulai dari informasi secara turun-temurun kemudian khasiat dikonfirmasi dengan hasil penelitian ilmiah. Salah satu tanaman tersebut adalah daun asam jawa (Tamarindus indica L). (Familia: Fabaceae). Sejak dulu asam jawa dikenal sebagai obat tradisional, bumbu dapur, kayu bangunan, dan merupakan salah satu komoditas ekspor potensial. Hampir semua bagian tanaman asam jawa dapat digunakan untuk berbagai keperluan sehingga tanaman ini disebut tanaman multiguna. Daun asam digunakan sebagai bumbu masakan, bahan obat, dan kosmetika. Bunga tanaman asam merupakan sumber madu yang penting bagi pengembangan budi daya lebah madu. Daging buah asam dimanfaatkan sebagai bumbu masakan dan campuran obat tradisional. Buah asam banyak digunakan dalam industri minuman, es krim, selai, manisan atau gulagula, sirup dan obat tradisional (Doughari, 2006).

Penelitian yang dilakukan oleh (Munim, dkk., 2009) menunjukkan bahwa ekstrak daun asam jawa memperlihatkan penghambatan $\alpha$-amilase, kemungkinan dapat digunakan sebagai alternatif pengobatan diabetes mellitus tipe 2. Ekstrak daun asam jawa telah diidentifikasi mengandung senyawa golongan kimia flavonoid, tanin, glikosida dan saponin. Tulisan ini dimaksudkan untuk menentukan konsentrasi yang efektif pada ekstrak daun asam jawa (Tamarindus indica L.) sebagai antidiabetes.

\section{Metode \\ Alat dan Bahan}

Alat-alat yang digunakan adalah gelas ukur, gelas kimia, labu ukur, corong, pissau/ cutter, spatula, batang pengaduk, penangas listrik, lumpang dan alu, kain flannel, pipet tetes, blender, thermometer, glukometer Dr (GlucoDr bio sensor AGM 2100, Allmedicus, Co, Ltd Korea), strip glukometer Dr (GM1439 GD, Allmedicus, Co, Ltd Korea), neraca digital, suntik, sonde, gunting, kandang hewan dan timbangan hewan. Bahan-bahan yang digunakan adalah daun asam jawa, mencit, etilen diamin tetra asetat (EDTA) (Merck), natrium karboksil metil selulosa (Na-CMC) (Merck), glibenklamid, glukosa 10\% (Merck $K g a A)$ dan Aquades.

\section{Cara Kerja \\ Preparasi Sampel}

Daun asam jawa yang masih hijau dibersihkan, kemudian dikeringkan dengan cara diangin-anginkan tanpa terkena sinar 
matahari secara langsung selama 14 hari. Selanjutnya daun asam jawa yang sudah kering dihancurkan menggunakan blender sampai halus. Serbuk daun asam jawa disaring menggunakan ayakan 60 mesh.

\section{Pembuatan Ekstrak Daun Asam Jawa}

Ekstrak daun asam jawa dibuat dengan metode infusa. Serbuk daun asam jawa sebanyak 10 gram dimasukkan ke dalam gelas kimia yang berisi aquades $100 \mathrm{~mL}$. Selanjutnya campuran dipanaskan pada suhu $90^{\circ} \mathrm{C}$ selama 15 menit. Setelah itu campuran didiamkan dan kemudian disaring menggunakan kain flannel, dan jika volume kurang dari $100 \mathrm{~mL}$, maka ditambahkan dengan air hangat melalui residu saringan hingga volumenya mencapai $100 \mathrm{~mL}$. Ekstrak daun asam jawa 20\% dan 40\% dibuat dengan cara yang sama dengan menggunakan $20 \mathrm{~g}$ dan $40 \mathrm{~g}$ serbuk daun asam jawa.

\section{Pembuatan Suspensi Na-CMC}

Suspensi $\mathrm{Na}-\mathrm{CMC} 1 \%$ dibuat dengan melarutkan 1 gram $\mathrm{Na}-\mathrm{CMC}$ sedikit demi sedikit ke dalam $50 \mathrm{~mL}$ air suling panas sambil diaduk hingga terbentuk suspensi. Volume dicukupkan hingga $100 \mathrm{~mL}$ dengan air suling Pembuatan Suspensi Glibenklamid

1 tablet glibenklamid $5 \mathrm{mg}$ digerus dalam lumpang, kemudian ditambahkan dengan suspensi $\mathrm{Na}-\mathrm{CMC} 1 \% \mathrm{~b} / \mathrm{v}$ sedikit demi sedikit sambil diaduk hingga homogen. Campuran dimasukkan dalam labu ukur $100 \mathrm{~mL}$ kemudian dicukupkan volumenya hingga $100 \mathrm{~mL}$ dengan suspensi $\mathrm{Na}-\mathrm{CMC} 1 \%$.

\section{Penyiapan dan Perlakuan Terhadap Hewan Uji}

Hewan uji yang digunakan adalah mencit (Mus musculus) jantan berbadan sehat, berumur 2-3 bulan dengan berat berkisar antara 2030 g. Mencit yang digunakan sebanyak 15 ekor dan dibagi dalam 5 kelompok perlakuan berdasarkan bahan uji yang terdiri dari tiga konsentrasi dan bahan pembanding positif dan negatif.

Masing-masing perlakuan terdiri dari 3 ekor mencit dan ketiga mencit tersebut diletakkan terpisah untuk setiap perlakuan. Mencit dipuasakan (tidak makan tetapi tetap minum) selama 4-5 jam. Kemudian berat badan ditimbang dan diukur kadar glukosa darah puasa pada hari ke-0. EDTA diinjeksikan sekali sebanyak $150 \mathrm{mg} / \mathrm{kgBB}$ secara intra vena. Setelah tiga hari (hari ke-3), kadar glukosa darah kembali diukur untuk memastikan kadar EDTA masih berfungsi sebagai diabetik eksperimental. Kemudian diberikan glukosa
$10 \%$ dan selama perlakuan mencit tetap diberikan pakan.

Perlakuan yang diberikan sebagai berikut:

Perlakuan I (P1): Pakan + EDTA + Glukosa $10 \%+$ Ekstrak daun asam jawa $10 \%+\mathrm{Na}-$ CMC 1\%; Perlakuan II (P2): Pakan + EDTA + Glukosa $10 \%$ + Ekstrak daun asam jawa 20\% + Na-CMC 1\%; Perlakuan III (P3): Pakan + EDTA + Glukosa 10\% + Ekstrak daun asam jawa $40 \%+$ Na-CMC 1\%; Perlakuan IV (P4): Sebagai kontrol positif (Pakan + EDTA + Glukosa 10\% + Glibenklamid + Na-CMC $1 \%$; Perlakuan V (P5): Sebagai kontrol negatif (Pakan + EDTA + Glukosa 10\% + Na-CMC $1 \%$.

Setelah diberikan perlakuan semua mencit diistrahatkan ke dalam kandangnya masingmasing dan diberikan makanan dan minuman. Kadar glukosa darah diukur kembali pada hari ke 1, 4 dan 7 yaitu pengukuran gula darah akhir.

\section{Penentuan Kadar Glukosa Darah}

Glukometer dihidupkan lebih dulu sebelum digunakan dan strip glukosa dimasukkan ke dalam glukometer. Darah diambil melalui ujung ekor hewan uji (mencit) kemudian diteteskan pada strip glukometer. Dalam waktu 10 detik kadar glukosa darah akan terukur secara otomatis dan hasilnya dapat dibaca pada monitor glukometer. Setelah data hasil glukosa darah awal diperoleh yang meliputi, glukosa darah setelah induksi, glukosa darah setelah perlakuan, dan penurunan glukosa dari kelima perlakuan tersebut. Selanjutnya dianalisis dan dievaluasi dengan menggunakan rencangan acak kelompok melalui uji statistik analisis ragam dengan taraf kepercayaan 95\%. Uji ini dilakukan untuk mengetahui perbedaan yang signifikan dari semua perlakuan, dan jika terdapat perbedaan maka pengujian dilanjutkan dengan uji Duncan untuk mengetahui perlakuan mana yang mempunyai perbedaan yang nyata.

\section{Hasil dan Pembahasan}

Ekstrak Daun Asam Jawa dan Penurunan Kadar Gula Darah Mencit

Ekstrak daun asam jawa diberikan pada hewan uji mencit (Mus musculus) jantan berbadan sehat, berumur 2-3 bulan dengan berat badan bervariasi antara 20-30 gram. Mencit selain ketersediaannya yang cukup tinggi, dan juga cukup peka untuk mewakili manusia dalam penentuan kadar glukosa darah. Hewan uji ini memiliki sistem metabolisme dan 
sistem pencernaan yang relatif sama dengan manusia (Salam, 2011).

Hewan uji mencit terlebih dahulu dipuasakan selama 4-5 jam, sebelum diberi perlakuan dengan tujuan untuk meminimalkan faktor makanan yang dapat mempengaruhi kadar gula darah. Meskipun demikian faktor variasi biologis dari hewan uji mencit tidak dapat dihilangkan, sehingga relatif dapat mempengaruhi hasil, karena terdapat perbedaan glukosa darah awal untuk setiap hewan uji. Setelah dipuasakan, kadar gula darah hewan uji mencit diukur dengan menggunakan alat GlukoDr. Sehari sebelum perlakuan, hewan uji terlebih dahulu diinduksi dengan menggunakan larutan etil diamin tetra asetat (EDTA). Fungsi dari pemberian larutan EDTA adalah untuk menghasilkan kondisi diabetik pada mencit sama halnya dengan diabetogen lainnya. Larutan EDTA dapat merusak substansi esensial di dalam sel $\beta$-pankreas sehingga menyebabkan berkurangnya insulin di dalam sel $\beta$-pankreas (Radiansah, 2013).

Mencit jantan digunakan pada penelitian ini karena dapat memberikan hasil penelitian yang lebih stabil dan tidak terpengaruhi oleh adanya siklus mentruasi dan kehamilan seperti pada mencit betina. Mencit jantan juga mempunyai kecepatan metabolisme obat yang lebih cepat dan kondisinya lebih stabil dibandingkan mencit betina (Mangkoewidjojo, 1988).

Kadar glukosa darah hewan uji mencit setelah diinduksi dengan larutan EDTA harus lebih dari $120 \mathrm{mg} / \mathrm{dL}$. Syarat untuk terjadinya keadaan hiperglikemia pada hewan uji adalah ketika kadar glukosa darah hewan uji mencapai $<120 \mathrm{mg} / \mathrm{dL}$. Oleh karena itu hewan uji diinduksi pada hari 1, 4, dan 7 agar kadar glukosa darah mencit mengalami kenaikan yang dapat memicu terjadinya diabetes (Evasuciany, dkk., 2010).

Hasil rerata kadar glukosa darah awal, setelah induksi, setelah perlakuan, dan penurunan glukosa darah setelah pemberian ekstrak daun asam jawa, dapat dilihat pada Tabel 1. Hasil tersebut menunjukkan bahwa rerata glukosa darah normal hewan uji mencit jantan berkisar 80,7-101 $\mathrm{mg} / \mathrm{dL}$. hal ini sesuai bahwa gula darah normal harus berada dalam rentang 60180 mg/dL (Radiansah, 2013)

Besaran penurunan glukosa darah pada mencit dapat diketahui melalui perhitungan selisih antara kadar glukosa darah setelah diinduksi dengan kadar glukosa darah setelah pemberian ekstrak daun asam jawa (Tamarindus Indica L.). Hasil penurunan kadar glukosa darah setelah diinduksi EDTA dikurangi dengan kadar glukosa darah setelah perlakuan. Kemudian dihitung reratanya seperti terlihat pada Tabel 1. Grafik yang memperlihatkan penurunan glukosa darah pada mencit terlihat pada Gambar 1.

Tabel 1. Rerata kadar glukosa darah awal, setelah induksi, setelah diberikan perlakuan dan penurunan glukosa darah setelah pemberian ekstrak daun asam jawa.

\begin{tabular}{ccccc}
\hline Perlakuan & $\begin{array}{c}\text { Glukosa } \\
\text { darah awal } \\
(\mathrm{mg} / \mathrm{dL})\end{array}$ & $\begin{array}{c}\text { Glukosa darah } \\
\text { setelah } \\
\text { induksi } \\
(\mathrm{mg} / \mathrm{dL})\end{array}$ & $\begin{array}{c}\text { Glukosa darah } \\
\text { setelah } \\
\text { perlakuan } \\
(\mathrm{mg} / \mathrm{dL})\end{array}$ & $\begin{array}{c}\text { Penurunan } \\
\text { glukosa darah } \\
(\mathrm{mg} / \mathrm{dL})\end{array}$ \\
\hline P1 & 111,3 & 201,3 & 158,7 & 42,7 \\
P2 & 80,7 & 186,0 & 153,0 & 33,0 \\
P3 & 101,0 & 208,0 & 152,0 & 56,0 \\
P4 & 105,0 & 196,3 & 143,0 & 53,3 \\
P5 & 103,3 & 194,7 & 170,3 & 24,3 \\
\hline
\end{tabular}

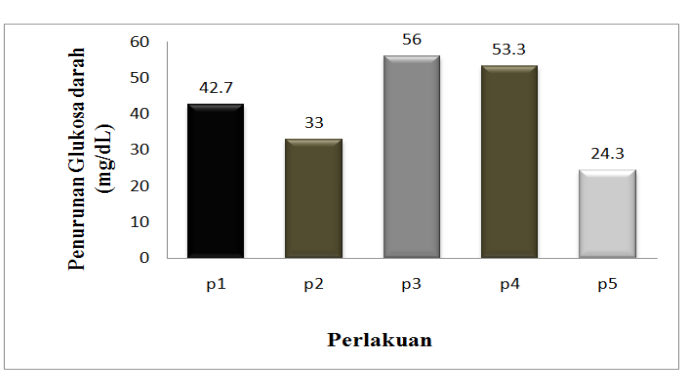

Gambar 1. Rerata penurunan glukosa darah

Data Tabel 1 menunjukkan bahwa rerata glukosa darah awal, glukosa darah setelah induksi, glukosa darah setelah perlakuan berbeda nyata antar beberapa perlakuan. Rerata penurunan glukosa darah terhadap hewan uji mencit, dapat dilihat perbedaan antar perlakuan. Perbedaan yang lebih nyata terlihat yaitu pada $\mathrm{P} 3$ atau pemberian ekstrak daun asam jawa 40\% dan P5 (kontrol negatif). Ini menunjukkan bahwa P3 atau pemberian ekstrak daun asam jawa 40\% efektif dalam menurunkan kadar glukosa darah terhadap hewan uji mencit (Mus musculus). Hasil yang diperoleh untuk rerata penurunan glukosa darah terhadap hewan uji mencit (Mus musculus) belum kembali ke keadaan normal, karena hanya tiga hari pemberian perlakuan ekstrak daun asam jawa, glukosa darah pada hewan uji mencit (Mus musculus) sudah mulai menurun. Seharusnya, pemberian obat herbal 
jangka waktu yang dibutuhkan cukup lama yaitu 7 sampai 14 hari bahkan sampai 21 hari, sangat berbeda dengan pemberian obat sintetik yang jangka waktunya tidak lama.

Penentuan adanya perbedaan yang signifikan antar kelima perlakuan dapat diketahui dengan menggunakan analisis ragam. Tabel 2 menunjukkan bahwa nilai $\mathrm{F}$ hitung antar kelompok 0,6527 lebih kecil dibandingkan dengan nilai $\mathrm{F}$ Tabel $5 \%$ yaitu 4,46. Hal ini menunjukkan tidak terjadi perbedaan yang signifikan antar kelompok. Jika terjadi perbedaan yang signifikan antar kelompok maka nilai $\mathrm{F}$ hitung lebih besar dibandingkan nilai $\mathrm{F}$ Tabel. Ada faktor yang mempengaruhi sehingga nilai $\mathrm{F}$ hitung yang diperoleh lebih kecil dari nilai $\mathrm{F}$ tabel, faktor tersebut adalah saat pemberian obat herbal dalam jangka waktu singkat (3 hari) rerata penurunan glukosa darah terhadap mencit mulai menurun, namun belum kembali ke keadaan normal.

Hasil konsentrasi yang lebih efektif dalam menurunkan kadar glukosa darah terhadap mencit dapat ditentukan dengan menggunakan uji Duncan, setelah uji ini dilakukan terlebih dahulu ditentukan koefisien keragamannya. Dari hasil perhitungan statistik diperoleh nilai koefisien keragaman yaitu 1,1963\%. Koefisien keragaman diperoleh dari hasil akar kuadrat tengah galat (KTG) di bagi jumlah kuadrat galat (JK galat) di kali 100\%. Nilai koefisien keragaman kurang dari 5\%, maka peneliti melanjutkan uji Duncan yaitu uji Beda Nyata Jujur (BNJ) dapat dilihat pada Tabel 3.

Tabel 3. Hasil Uji BNJ

\begin{tabular}{ccc}
\hline Perlakuan & Rerata penurunan kadar glukosa darah (mg/dl) & wilayah \\
\hline P5 (-) & 24,3 & a \\
P2 & 33,0 & a \\
P1 & 42,7 & a \\
P4 $(+)$ & 53,3 & b \\
P3 & 56,0 & b \\
\hline
\end{tabular}

Keterangan : P5 : kontrol negatig (-); P2 : konsentrasi ekstrak daun asam jawa 20\%; P1 : konsentrasi ekstrak daun asam jawa 10\%; P4 : kontrol positif (+); P3 : konsentrasi ekstrak daun asam jawa $40 \%$.

Berdasarkan hasil perhitungan statistik uji beda nyata jujur seperti pada Tabel 3, penurunan glukosa darah dengan taraf signifikan 5\% menunjukkan pemberian ekstrak
10\% P1, ekstrak 20\% P2 dan (kontrol negatif) pemberian tanpa ekstrak P5 menunjukkan perbedaan yang nyata jika dibandingkan dengan perlakuan lainnya. Pemberian ekstrak 40\% (P3) berbeda signifikan dengan kontrol negatif (P5), namun tidak berbeda signifikan dengan obat glibenklamid (P4). Artinya pemberian ekstrak 40\% (P3) memberi efek dapat menurunkan kadar glukosa darah hewan uji mencit. Keefektifan ekstrak daun asam jawa dalam menurunkan kadar glukosa darah dipengaruhi oleh senyawa bioaktif yang terkandung pada ekstrak daun asam jawa yaitu flavonoid, tanin, glikosida dan saponin (Munim dkk., 2009).

Flavonoid juga memiliki aktifitas hipoglikemik dengan menghambat enzimenzim penting yang berperan dalam pemecahan karbohidrat menjadi monosakarida yang dapat diserap oleh usus yaitu enzim $\alpha$ amilase dan enzim $\alpha$ glukosidase. Enzim glukosidase merupakan enzim yang juga digunakan untuk mengetahui potensi suatu tumbuhan sebagai antidiabetes secara in vitro dengan mekanisme penghambatan. Selain itu, Flavonoid mempunyai sifat sebagai antioksidan sehingga dapat melindungi kerusakan sel-sel pankreas dari radikal bebas (Kendran dkk., 2010). Tanin dapat mengendapkan protein selaput lendir di permukaann usus halus atau membentuk suatu lapisan yang melindungi usus halus dan membentuk suatu lapisan yang melindungi usus. Tanin terbukti dapat menghambat absorbsi glukosa sehingga laju peningkatkan glukosa darah tidak terlalu tinggi (Meiyanti, dkk., 2006).

\section{Kesimpulan}

EKonsentrasi yang efektif dalam menurunkan kadar glukosa darah terhadap hewan uji mencit adalah pada konsentrasi $40 \%$ atau perlakuan tiga (P3) / menggunakan ekstrak daun asam jawa $40 \mathrm{~g}(\mathrm{~b} / \mathrm{v})$.

\section{Ucapan Terima Kasih}

Penulis mengucapkan terima kasih kepada Laboratorium Agroteknologi FAPERTA Universitas Tadulako dan Balai Litbang P2B2 Donggala Kemenkes serta semua pihak yang telah banyak membantu penulis dalam menyelesaikan artikel ini. 


\section{Referensi}

Baroroh, F. (2011). Uji efek antihiperglikemik ekstrak etanol daun kacapirig (garedenia augusta, merr) pada tikus jantan galur wistar.Jurnal Ilmiah Kefarmasian, 1(1), 4353.

Doughari, J., H. (2006). Antimicrobial activity of Tamarindus indica Linn. Surabaya: Grafika.

Dyahnugrah, A. A. , \& Widjanarko, S. B. (2015). Ekstrak bubuk kulit manggis menurunkan kadar glukosa darah tikus. Jurnal Pangan dan Agroindustri, 3(1), 113123.

Evasuciany, E., Delima, E. R., \& Boen, R. (2010). The effect of morinda citrifolia L. ethanol extract on blood in alloxan induced male mice swiss webster strain.Jurnal Medika Planta, 1(1), 87-92.

Galih, P. R. , \& Esyanti, R. R. (2014). Effect of immobilization on cell growth and alkaloid content in cell-agggregate culture of Eurycoma longifolia jack.International Journal of Chemical, Environmental \& Biological Sciences (IJCEBS), 2(2), 90-93.

Inawati, Syamsudin., \& Winarno, H. (2006). Pengaruh ekstrak daun inai (Lawsonia Inermis Linn) terhadap penurunan kadar glukosa kolesterol total dan trigliserida darah mencit yang di induksi aloksan.Jurnal Kimia Indonesia., 1(2), 71-77.

Kendran, A. S., Tono, S., Pertiwi, N. L., Dharmayuda, G. , \& Anggreni, L. D. (2010). Effect of physalis minina Linn. Psidium guajana Linn. Sweitenia mahgoni jacq ethanol extract againts bood glucose level.Jurnal Medika Planta, 1(2), 56-60.

Mangkoewidjojo. (1988). Pemeliharaan, pembiakan dan penggunaan hewan percobaan di daerah tropis. Jakarta: UI Press.

Meiyanti, Dewoto H. R. , \& Suyatna, F. D. (2006). Efek hipoglikemik daging buah mahkota dewa (phaleria macrocarpa (scheff) boerl.) terhadap kadar gula darah pada manusia sehat setelah pemberian glukosa. Jurnal Universa Medicina, 3(25), 114-120.

Munim, A., Hanani, E. , \& Rahmadiah. (2009). Karakterisasi ekstrak etanolik daun asam jawa (Tamarindus indica L.).Majalah Ilmu Kefarmasian, 4(1), 38-44.

Radiansah, R. (2013). Ekstrak daun kelor (Moringa Oleivera) sebagai alternatif untuk menurunkan kadar gula darah pada mencit. Tidak diterbitkan. Skripsi, Universitas Tadulako Palu.

Salam, A. A. (2011). Pengaruh konsentrasi infusa daun lere (ipomea pes-caprea (L) roth br) terhadap penurunan kadar glukosa darah kelinci (orytolagus cunniculus). Tidak diterbitkan. Skripsi, Universitas Tadulako Palu.

Sukandar, D., Sumarlin, L. O., Zahro, H. , \& Amelia, E. R. (2012). Uji aktifitas antidiabetes fraksi etil asetat daun pandan wangi (P. amaryllifolius roxb.) dengan metode $\alpha$-glukosidase.Valensi, 2(5), 534540.

Sutjiatmo, A., Sukandar E.Y., Ratnawati Y., Kusmaningati S., Wulandari A. , \& Narvikasari, S. (2011). Efek antidiabetes herba ciplukan (physalis angulata LINN.) pada mencit diabetes dengan induksi aloksan.Jurnal Farmasi Indonesia, 5(4), 166171.

Trihono. (2013). Riset Kesehatan Dasar 2013. Badan Penelitian dan Pengembangan Kesehatan Kementrian Kesehatan Republik Indonesia Tahun 2013. Jakarta.

Waspadji, S. (2007). Diabetes melitus apakah itu dalam hidup sehat dengan diabetes. Jakarta: Balai Penerbit FKUI.

Zubaidah, E. (2011). Pengaruh pemberian cuka apel dan cuka salak terhadap kadar glukosa darah tikus wistar yang diberi diet tinggi gula.Jurnal Teknologi Pertanian, 12(3), 163169. 